\title{
Sterenin A, B, C and D, Novel $11 \beta$-Hydroxysteroid Dehydrogenase Type 1 Inhibitors from Stereum sp. SANK 21205
}

\author{
Mariko Ito-Kobayashi, Azusa Aoyagi, Isshin Tanaka, Yasunori Muramatsu, \\ Megumi Umetani, Toshio Takatsu
}

Received: November 12, 2007 / Accepted: February 26, 2008

(C) Japan Antibiotics Research Association

\begin{abstract}
The novel $11 \beta$-hydroxysteroid dehydrogenase type 1 (11 $\beta$-HSD1) inhibitors known as sterenin A, B, C and $\mathrm{D}$ were found in a solid-state culture of the producing basidiomycetes identified as Stereum sp. SANK 21205. Purification of the $50 \%$ aq $\mathrm{Me}_{2} \mathrm{CO}$ extract of the culture was performed by EtOAc extraction, reversed phase opencolumn chromatography and successive ODS HPLC preparation. These compounds, whose structures were determined by several spectroscopic methods, were found to be novel isoindolinone alkaloids which exhibited potent selective inhibitory activities against $11 \beta$-HSD1.
\end{abstract}

Keywords sterenin, $11 \beta$-HSD1 inhibitor, Stereum, taxonomy, fermentation, isolation, structure

\section{Introduction}

Metabolic syndrome is a general term referring to the accumulation of associated disorders characterized by insulin resistance, obesity, dyslipidemia and hypertension, which are major risk factors for cardiovascular diseases and atherosclerosis. Among the many factors that play a role in this syndrome, glucocorticoids have received considerable attention. Excess glucocorticoid levels cause glucose intolerance and insulin resistance, clinically indicating Cushing's syndrome [1, 2], which closely resembles metabolic syndrome. Accumulated evidence suggests that $11 \beta$-hydroxysteroid dehydrogenase (11 $\beta$-HSD), an enzyme responsible for producing glucocorticoids in tissues, is upregulated in obesity subjects, including humans [3 5]. Targeted disruption of $11 \beta$-HSD in mice exhibits a protective glycemic, lipid and lipoprotein profile. As glucocorticoids oppose the insulin effect, several studies with mice lacking [6] or overexpressing [7] $11 \beta$-HSD1 reported that $11 \beta$-HSD1 plays an important role in Type 2 diabetes and metabolic syndrome. Thus, an $11 \beta$-HSD1 inhibitor is expected to be a promising target in the treatment of metabolic syndrome.

In the course of screening natural products with $11 \beta$ HSD1 inhibitory activity, one basidiomycete was found to be the active compound producer designated Stereum sp. SANK 21205. Here, we describe the taxonomy of the producing organism, and the fermentation, isolation, structural elucidation and biological activities of sterenin A, B, C and D (Fig. 1), which are novel 11 $\beta$-HSD1 inhibitors.
T. Takatsu (Corresponding author), A. Aoyagi, I. Tanaka: Advanced Technology Research Laboratories, Daiichi Sankyo Co., Ltd., 1-2-58 Hiromachi, Shinagawa-ku, Tokyo 140-8710, Japan, E-mail: takatsu.toshio.c2@daiichisankyo.co.jp

M. Ito-Kobayashi: Exploratory Research Laboratories II, Daiichi Sankyo Co., Ltd., 1-16-13 Kitakasai, Edogawa-ku, Tokyo 1348630, Japan
Y. Muramatsu, M. Umetani: Exploratory Research Laboratories I, Daiichi Sankyo Co., Ltd., 1-16-13 Kitakasai, Edogawa-ku, Tokyo 134-8630, Japan 


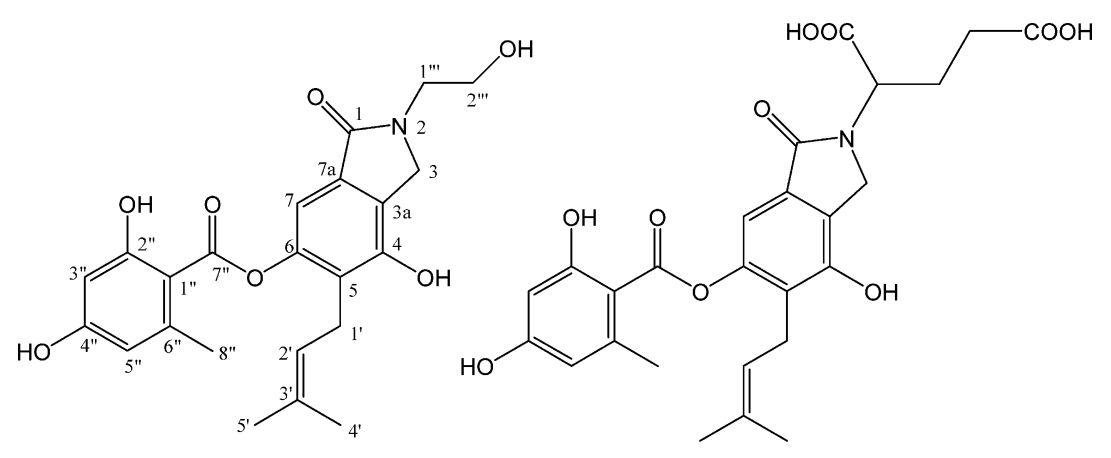

Sterenin A

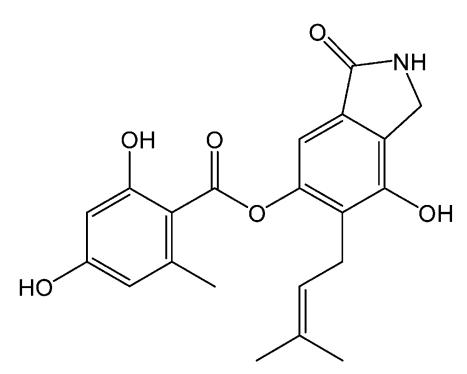

Sterenin C

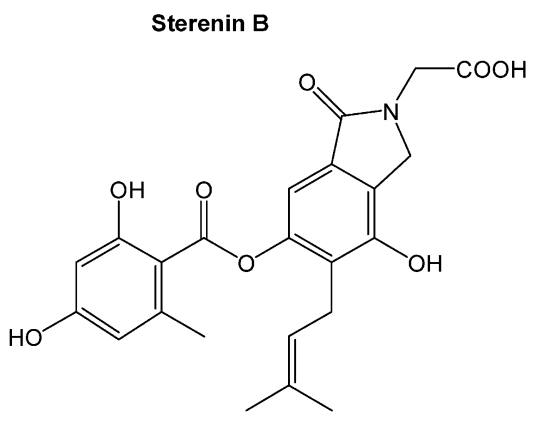

Sterenin D

Fig. 1 Structures of sterenin A, B, C and D.

\section{Materials and Methods}

\section{General}

The ${ }^{1} \mathrm{H}$ - and ${ }^{13} \mathrm{C}$-NMR spectra were recorded at $298 \mathrm{~K}$ on an AVANCE 500 spectrometer equipped with a cryogenic probe (Bruker BioSpin) operating at $500 \mathrm{MHz}$ and $125 \mathrm{MHz}$, respectively. The samples for NMR characterization were dissolved in $\mathrm{CD}_{3} \mathrm{OD}$. The optical rotation and IR spectra were measured with a DIP-370 (JASCO) and a VALOR-III (JASCO), respectively. The mass spectra and high-resolution mass spectra were measured with a JMS700QV Mstation (JEOL). HPLC analysis was carried out with an HP1100 system (Agilent).

\section{Preparation of $11 \beta$-HSD1-expressing Microsomes}

Human and mouse $11 \beta$-HSD1 cDNA were amplified by RT-PCR and sub-cloned into a pCIneo (Promega) expression vector. Expression plasmid was transfected into Hek293 cells using Lipofectamine plus reagent (Invitrogen). At 48 hours post-transfection, the cells were harvested, suspended in Hepes buffer $(20 \mathrm{mM}$ Hepes $(\mathrm{pH}$ 7.4), $1.0 \mathrm{mM}$ EDTA, $2.0 \mathrm{mM} \mathrm{MgCl}{ }_{2}$ and protease inhibitor cocktail (Roche)) and disrupted by $\mathrm{N}_{2}$ cavitation at 4.1 MPa. The cell homogenates were centrifuged for 10 minutes at $1,000 \mathrm{~g}$ and the pellets were discarded. The supernatants were re-centrifuged at $105,000 \mathrm{~g}$ for 30 minutes. The pellets were re-suspended in reaction buffer (50 mM Tris (pH7.4), 10\% glycerol).

\section{1 $\beta$-HSD1 Reductase Assay}

The microsomes were incubated in reaction buffer for 3 hours at room temperature $\left(26^{\circ} \mathrm{C}\right)$ with an NADPH generation system $(0.8 \mathrm{mM}$ NADPH, $6.0 \mathrm{mM}$ glucose-6phosphate, $0.35 \mathrm{U} / \mathrm{ml}$ glucose-6-phosphate dehydrogenase, $3.0 \mathrm{mM} \mathrm{MgCl}_{2}$ ), respective concentrations of sterenins and $160 \mathrm{nM}$ of substrate (human: cortisone, mouse: 11-dehydrocorticosterone). The reaction was stopped by adding $50 \mu \mathrm{M}$ of carbenoxolone and the product (human: cortisol, mouse: corticosterone) concentration was determined using HTRF Cortisol Assay Reagents (Cisbio).

\section{Preparation of $11 \boldsymbol{\beta}$-HSD2-expressing Microsomes}

Human $11 \beta$-HSD2 cDNA was amplified by RT-PCR and sub-cloned into $\mathrm{pFastBac}$ vector (Invitrogen). Recombinant baculovirus was generated using a Bac-to-Bac Baculovirus Expression System (Invitrogen). Sf9 insect cells infected with baculovirus were harvested 48 hours after infection and microsomes were prepared in the same way as described above.

\section{$11 \beta$-HSD2 Dehydrogenase Assay}

The microsomes were incubated in reaction buffer for 20 
minutes at room temperature $\left(26^{\circ} \mathrm{C}\right)$ with $43 \mu \mathrm{M}$ of NAD, respective concentrations of sterenins and $160 \mathrm{nM}$ of cortisol. The reaction was terminated by the addition of $50 \mu \mathrm{M}$ of carbenoxolone and the cortisol concentration was determined using HTRF Cortisol Assay Reagents.

\section{Results}

\section{Taxonomy of the Producing Organism}

The producing strain, SANK 21205, was isolated from the spore print of fresh basidiocarps collected in Gunma Prefecture, Japan. As this basidiomycete could not be characterized by its cultural features, the observation of dried basidiocarps was needed for identification. The morphological characteristics of the dried basidiocarps are shown in Fig. 2.

The basidiocarps were resupinate to effused-reflexed. The pilei were up to $5.0 \mathrm{~mm}$ in width, up to $0.4 \mathrm{~mm}$ in thickness, dimidiate to flabellate, and were usually coalescent and tough. The upper surface was hirsute and grayish white. The margin of the pilei was thin and acute. The hymenial surface was smooth to slightly tuberculate and pale orange. Cutis was present, which was brown and up to $25 \mu \mathrm{m}$ in thickness.

The basidiospores were $8.0 \sim 12.0 \times 3 \sim 4.0 \mu \mathrm{m}$, cylindrical, often slightly curved, thin-walled, smooth, and amyloid. The basidia were $40 \sim 50 \times 5.0 \sim 6.0 \mu \mathrm{m}$, narrowly clavate, with 4 sterigamata, which were up to $4.0 \mu \mathrm{m}$ in

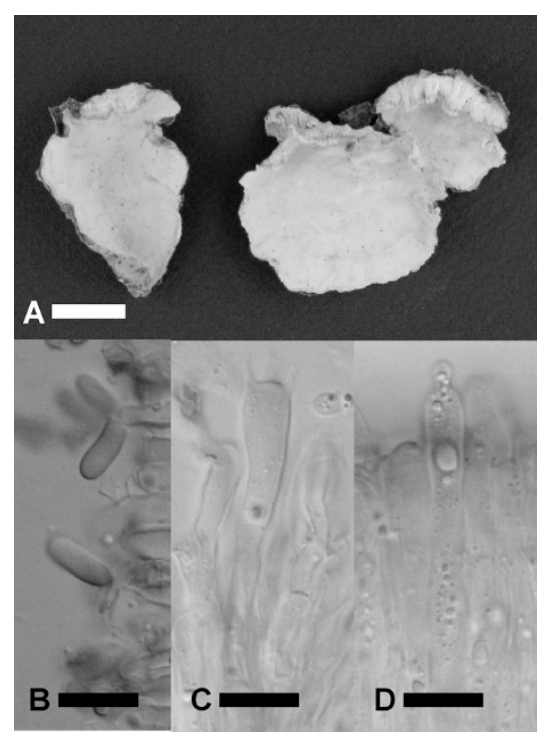

Fig. 2 Morphological characteristics of Stereum sp.

A: Basidiocarps. B: Basidiospores. C: Basidium. D: Pseudocystidium. Scales: $A=10 \mathrm{~mm} ; \mathrm{B} \sim \mathrm{D}=10 \mu \mathrm{m}$. length. The pseudocystidia were $4.5 \sim 6.0 \mu \mathrm{m}$ in width, cylindrical, thick-walled at the base (up to $2.0 \mu \mathrm{m}$ ), thinwalled at the apex, often with small points. The hyphal system was monomitic. The hyphae were $2.0 \sim 6.0 \mu \mathrm{m}$ in width, thin-walled to thick-walled, and without clamp connections. Acanthohyphidia or pseudoacanthohyphidia were not observed.

The above characteristics of the basidiocarps corresponded with the description of the genus Stereum [8]. Hence, the strain was identified as Stereum sp. This strain has been deposited at the National Institute of Advanced Industrial Science and Technology, Japan, as Stereum sp. SANK 21205 under the accession number FERM BP10465.

\section{Fermentation}

The growth of Stereum sp. SANK 21205 on an agar slant $\left(1 \mathrm{~cm}^{3}\right)$ was homogenized with sterile water $(3.0 \mathrm{ml})$. Then the whole amount of the homogenate was transferred into a 100-ml Erlenmeyer flask containing $30 \mathrm{ml}$ of a sterilized liquid seed medium composed of glucose $0.4 \%$, malt extract $1.0 \%$, yeast extract $0.4 \%$, agar $0.3 \%$ and Disfoam CB-442 (Nippon Yushi Co.) $0.005 \%$. The flask was incubated at $23^{\circ} \mathrm{C}$ for 7 days on a rotary shaker at $210 \mathrm{rpm}$. The seed culture $(30 \mathrm{ml})$ was transferred into a $500-\mathrm{ml}$ AGRIFLEX bag (Fujimori Kogyo Co., Ltd.) containing a sterilized production medium which was composed of brown rice $90 \mathrm{~g}, \mathrm{NaNO}_{3} 0.05 \mathrm{~g}, \mathrm{KH}_{2} \mathrm{PO}_{4} \quad 0.05 \mathrm{~g}$, $\mathrm{MgSO}_{4} \cdot 7 \mathrm{H}_{2} \mathrm{O} \quad 0.05 \mathrm{~g}$ and distilled water $100 \mathrm{ml}$. The fermentation was carried out at $23^{\circ} \mathrm{C}$ for 14 days by stationary cultivation.

\section{Isolation}

An equal volume of $\mathrm{Me}_{2} \mathrm{CO}$ was added to the harvested culture (3.0 liters, 60 bags), which was left stirring for 30 minutes. And then, the extract was filtered by the aid of diatomaceous earth (Celite Co., $150 \mathrm{~g}$ ). The yielded filtrate was adjusted to $\mathrm{pH} 3.0$ with $6 \mathrm{M} \mathrm{HCl}$ and the active substance was extracted by EtOAc (3.5 liters). The extract was washed with saturated brine (2.0 liters) and dried over anhydrous $\mathrm{Na}_{2} \mathrm{SO}_{4}$ for 1 hour. The filtered extract was concentrated in vacuo to dryness to obtain oily material $(13 \mathrm{~g})$. The material was dissolved into $\mathrm{MeOH}(50 \mathrm{ml})$ and reversed phase silica gel powder (Cosmosil $140 \mathrm{C}_{18}$-OPN, Nakalai Tesque, $60 \mathrm{~g}$ ) was added to the solution by stirring. After the removal of the $\mathrm{MeOH}$ by evaporation, $0.3 \%$ triethylamine-phosphate buffer $(\mathrm{pH} 3.0,400 \mathrm{ml})$ was added to the material adsorbed powder to make slurry. The obtained slurry was layered onto the Cosmosil $140 \mathrm{C}_{18}$-OPN column $(600 \mathrm{ml})$ equilibrated with $10 \% \mathrm{CH}_{3} \mathrm{CN}$ in $\mathrm{H}_{2} \mathrm{O}$ containing $0.3 \%$ triethylamine-phosphate buffer ( $\mathrm{pH} 3.0$ ). 
Table 1 Physico-chemical properties of sterenin A, B, C and D

\begin{tabular}{|c|c|c|c|c|}
\hline & Sterenin A & Sterenin B & Sterenin C & Sterenin D \\
\hline Appearance & White powder & White powder & White powder & White powder \\
\hline Molecular formura & $\mathrm{C}_{23} \mathrm{H}_{25} \mathrm{NO}_{7}$ & $\mathrm{C}_{26} \mathrm{H}_{27} \mathrm{NO}_{10}$ & $\mathrm{C}_{21} \mathrm{H}_{21} \mathrm{NO}_{6}$ & $\mathrm{C}_{23} \mathrm{H}_{23} \mathrm{NO}_{8}$ \\
\hline FAB-MS $(m / z)$ & $450(\mathrm{M}+\mathrm{Na})^{+}$ & $514(\mathrm{M}+\mathrm{H})^{+}$ & $406(\mathrm{M}+\mathrm{Na})^{+}$ & $441(\mathrm{M}+\mathrm{H})^{+}$ \\
\hline HRFAB-MS (m/z) & for $\mathrm{C}_{23} \mathrm{H}_{25} \mathrm{NO}_{7} \mathrm{Na}$ & for $\mathrm{C}_{26} \mathrm{H}_{28} \mathrm{NO}_{10}$ & for $\mathrm{C}_{21} \mathrm{H}_{21} \mathrm{NO}_{6} \mathrm{Na}$ & for $\mathrm{C}_{23} \mathrm{H}_{24} \mathrm{NO}_{8}$ \\
\hline Found: & 450.1526 & 514.1697 & 406.1273 & 442.1495 \\
\hline Calcd.: & 450.1529 & 514.1713 & 406.1267 & 442.1502 \\
\hline$[\alpha]_{D}^{31}$ & - & $-13.6^{\circ}$ (c 0.5, MeOH) & - & - \\
\hline$U V \lambda_{\max }^{\mathrm{MeOH}} \mathrm{nm}(\varepsilon)$ & $\begin{array}{l}212(58600), 265(24400) \\
297(10900)\end{array}$ & $\begin{array}{l}214(58100), 265(26500) \\
296(11100)\end{array}$ & $\begin{array}{l}213(66700), 268 \text { (23000) } \\
297(12000)\end{array}$ & $\begin{array}{l}213 \text { (96200), } 265 \text { (41300) } \\
297 \text { (17500) }\end{array}$ \\
\hline IR $v_{\max }^{\mathrm{KBr}} \mathrm{cm}^{-1}$ & $\begin{array}{l}3357,3231,2973,2931 \\
1662,1623,1602,1456 \\
1376,1311,1255,1199 \\
1164,1084,1064,1035 \\
990\end{array}$ & $\begin{array}{l}3348,3264,2973,2928 \\
2858,1718,1662,1624 \\
1603,1450,1413,1377 \\
1310,1254,1198,1162 \\
1087,1063,1035,991\end{array}$ & $\begin{array}{l}\text { 3409, 3267, 2974, 2931, } \\
1669,1653,1623,1599, \\
1504,1446,1413,1374, \\
1349,1313,1255,1193 \\
1173,1161,1100,1063, \\
1038,998,989\end{array}$ & $\begin{array}{l}3366,3245,2973,2929, \\
2733,1662,1624,1601, \\
1458,1448,1401,1377, \\
1311,1254,1201,1165, \\
1103,1081,1035,995, \\
946\end{array}$ \\
\hline \multicolumn{5}{|l|}{ Solubility } \\
\hline Soluble & EtOAc, $\mathrm{MeOH}, \mathrm{DMSO}$ & EtOAc, MeOH, DMSO & EtOAc, MeOH, DMSO & EtOAc, MeOH, DMSO \\
\hline
\end{tabular}
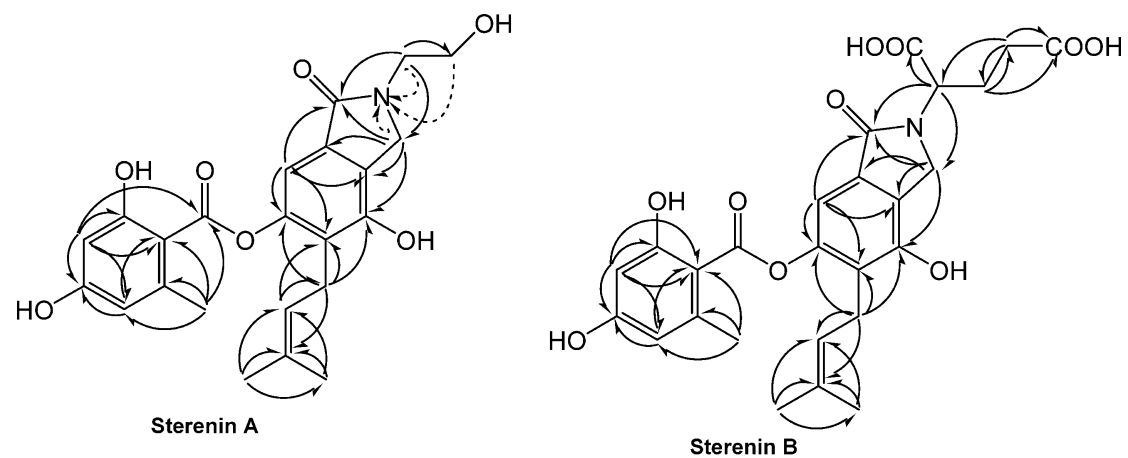

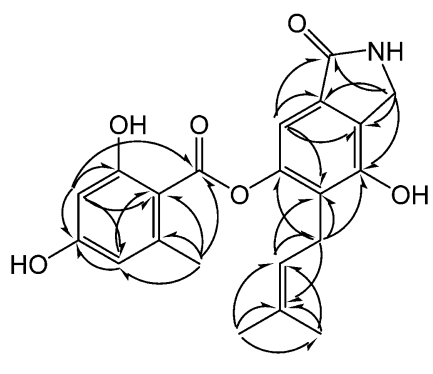

Sterenin C

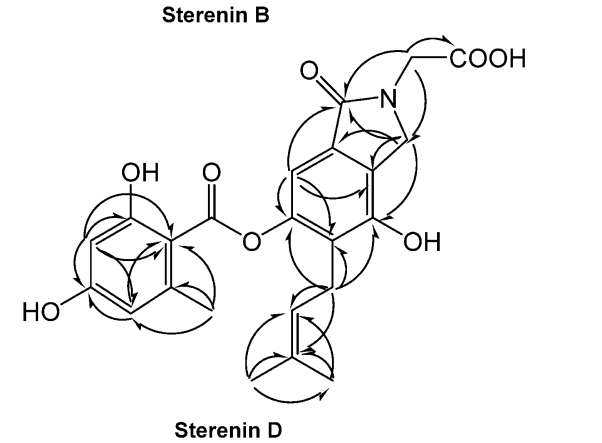

${ }^{1} \mathrm{H}-{ }^{13} \mathrm{C}$ long-range coupling

-... ${ }^{1} \mathrm{H}-{ }^{15} \mathrm{~N}$ long-range coupling

Fig. $3 \quad{ }^{1} \mathrm{H}^{13}{ }^{3} \mathrm{C}$ and ${ }^{1} \mathrm{H}-{ }^{15} \mathrm{~N}$ long-range couplings of sterenin $\mathrm{A}, \mathrm{B}, \mathrm{C}$ and $\mathrm{D}$.

The column was washed successively with systems of the same solvent of 10, 20 and $25 \%$ (1.0 liter each) and the active material was eluted by $30 \% \mathrm{CH}_{3} \mathrm{CN}-\mathrm{H}_{2} \mathrm{O}$ containing
$0.3 \%$ triethylamine-phosphate buffer ( $\mathrm{pH} \mathrm{3.0,} 3.0$ liters). The fraction which contained sterenin $\mathrm{A}, \mathrm{B}, \mathrm{C}$ and $\mathrm{D}$ $(500 \mathrm{ml})$ was concentrated in vacuo to remove $\mathrm{CH}_{3} \mathrm{CN}$ and 
Table 2 NMR spectral data of sterenin $A, B, C$ and $D$ in $C_{3} O D$

\begin{tabular}{|c|c|c|c|c|c|c|c|c|c|}
\hline \multirow{2}{*}{ Position } & \multicolumn{3}{|c|}{ Sterenin A } & \multicolumn{2}{|c|}{ Sterenin B } & \multicolumn{2}{|c|}{ Sterenin C } & \multicolumn{2}{|c|}{ Sterenin D } \\
\hline & $\delta_{\mathrm{C}}\left(\mathrm{m}^{\mathrm{a}}\right)$ & $\delta_{\mathrm{H}}(\mathrm{m}, \mathrm{J}$ in $\mathrm{Hz})$ & $\delta_{\mathrm{N}}$ & $\delta_{\mathrm{C}}(\mathrm{m})$ & $\delta_{\mathrm{H}}(\mathrm{m}, J$ in $\mathrm{Hz})$ & $\delta_{\mathrm{C}}(\mathrm{m})$ & $\delta_{\mathrm{H}}(\mathrm{m}, J$ in $\mathrm{Hz})$ & $\delta_{\mathrm{C}}(\mathrm{m})$ & $\delta_{\mathrm{H}}(\mathrm{m}, J$ in $\mathrm{Hz})$ \\
\hline 1 & $170.7 \mathrm{~s}$ & & & $171.3 \mathrm{~s}$ & & $173.4 \mathrm{~s}$ & & $170.8 \mathrm{~s}$ & \\
\hline 2 & & & 123 & & & & & & \\
\hline 3 & $50.9 t$ & $4.58(2 \mathrm{H}, \mathrm{s})$ & & $46.9 t$ & $\begin{array}{l}4.46(1 \mathrm{H}, \mathrm{d}, 16.9) \\
4.58(1 \mathrm{H}, \mathrm{d}, 16.9)\end{array}$ & $45.0 t$ & $4.40(2 \mathrm{H}, \mathrm{s})$ & $50.3 t$ & $4.54(2 \mathrm{H}, \mathrm{s})$ \\
\hline 3а & $127.2 \mathrm{~s}$ & & & $127.5 \mathrm{~s}^{\mathrm{b}}$ & & $129.3 \mathrm{~s}$ & & $127.5 \mathrm{~s}^{\mathrm{b}}$ & \\
\hline 4 & $152.4 \mathrm{~s}$ & & & $152.4 \mathrm{~s}$ & & $152.6 \mathrm{~s}$ & & $152.4 \mathrm{~s}$ & \\
\hline 5 & $127.1 \mathrm{~s}$ & & & $127.3 s^{b}$ & & $127.3 \mathrm{~s}$ & & $127.3 s^{b}$ & \\
\hline 6 & $151.3 \mathrm{~s}$ & & & $151.4 \mathrm{~s}$ & & $151.4 \mathrm{~s}$ & & $151.4 \mathrm{~s}$ & \\
\hline 7 & $110.1 \mathrm{~d}$ & $7.08(1 \mathrm{H}, \mathrm{s})$ & & $110.4 d$ & $7.09(1 \mathrm{H}, \mathrm{s})$ & $110.2 \mathrm{~d}$ & $7.08(1 \mathrm{H}, \mathrm{s})$ & $110.4 d$ & $7.08(1 \mathrm{H}, \mathrm{s})$ \\
\hline $7 a$ & $132.7 \mathrm{~s}$ & & & $132.0 \mathrm{~s}$ & & $132.5 \mathrm{~s}$ & & $132.1 \mathrm{~s}$ & \\
\hline $1^{\prime}$ & $24.7 \mathrm{t}$ & $3.37(2 \mathrm{H}, \mathrm{m})$ & & $24.8 \mathrm{t}$ & $3.39(2 \mathrm{H}, \mathrm{m})$ & $24.7 \mathrm{t}$ & $3.38(2 \mathrm{H}, \mathrm{m})$ & $24.8 \mathrm{t}$ & $3.39(2 \mathrm{H}, \mathrm{m})$ \\
\hline $2^{\prime}$ & $122.7 \mathrm{~d}$ & $5.03(1 \mathrm{H}, \mathrm{m})$ & & $122.7 d$ & $5.04(1 \mathrm{H}, \mathrm{m})$ & $122.7 \mathrm{~d}$ & $5.03(1 \mathrm{H}, \mathrm{m})$ & $122.7 d$ & $5.04(1 \mathrm{H}, \mathrm{m})$ \\
\hline $3^{\prime}$ & $133.3 \mathrm{~s}$ & & & $133.3 \mathrm{~s}$ & & $133.3 \mathrm{~s}$ & & $133.3 \mathrm{~s}$ & \\
\hline $4^{\prime}$ & $17.9 q$ & $1.50(3 \mathrm{H}, \mathrm{s})$ & & $17.9 q$ & $1.52(3 \mathrm{H}, \mathrm{s})$ & $17.9 \mathrm{q}$ & $1.50(3 \mathrm{H}, \mathrm{s})$ & $17.9 q$ & $1.50(3 \mathrm{H}, \mathrm{s})$ \\
\hline $5^{\prime}$ & $25.9 q$ & $1.56(3 \mathrm{H}, \mathrm{s})$ & & $25.9 q$ & $1.57(3 \mathrm{H}, \mathrm{s})$ & $25.9 q$ & $1.57(3 \mathrm{H}, \mathrm{s})$ & $25.9 q$ & $1.57(3 \mathrm{H}, \mathrm{s})$ \\
\hline $1^{\prime \prime}$ & $105.3 \mathrm{~s}$ & & & $105.3 \mathrm{~s}$ & & $105.3 \mathrm{~s}$ & & $105.3 \mathrm{~s}$ & \\
\hline $2^{\prime \prime}$ & $167.1 \mathrm{~s}$ & & & $167.1 \mathrm{~s}$ & & $167.1 \mathrm{~s}$ & & $167.1 \mathrm{~s}$ & \\
\hline $3^{\prime \prime}$ & $102.0 \mathrm{~d}$ & $6.23(1 \mathrm{H}$, br. s) & & $102.0 d$ & $6.24(1 \mathrm{H}$, br. s) & $102.0 \mathrm{~d}$ & $6.22(1 \mathrm{H}$, br. s) & $102.0 \mathrm{~d}$ & $6.23(1 \mathrm{H}$, br. s) \\
\hline $4^{\prime \prime}$ & $164.9 \mathrm{~s}$ & & & $164.9 \mathrm{~s}$ & & $164.9 \mathrm{~s}$ & & $164.9 \mathrm{~s}$ & \\
\hline $5^{\prime \prime}$ & $113.1 d$ & $6.31(1 \mathrm{H}$, br. s) & & $113.1 \mathrm{~d}$ & $6.31(1 \mathrm{H}$, br. s) & $113.1 \mathrm{~d}$ & $6.30(1 \mathrm{H}$, br. s) & $113.1 \mathrm{~d}$ & $6.30(1 \mathrm{H}$, br. s) \\
\hline $6^{\prime \prime}$ & $145.1 \mathrm{~s}$ & & & $145.1 \mathrm{~s}$ & & $145.1 \mathrm{~s}$ & & $145.1 \mathrm{~s}$ & \\
\hline $7^{\prime \prime}$ & $171.8 \mathrm{~s}$ & & & $171.8 \mathrm{~s}$ & & $171.8 \mathrm{~s}$ & & $171.8 \mathrm{~s}$ & \\
\hline $8^{\prime \prime}$ & $24.7 \mathrm{q}$ & $2.60(3 \mathrm{H}, \mathrm{s})$ & & $24.7 \mathrm{q}$ & $2.60(3 \mathrm{H}, \mathrm{s})$ & $24.7 q$ & $2.60(3 \mathrm{H}, \mathrm{s})$ & $24.7 q$ & $2.61(3 \mathrm{H}, \mathrm{s})$ \\
\hline $1^{\prime \prime \prime}$ & $46.5 t$ & $3.75(2 \mathrm{H}, \mathrm{t}, 5.1)$ & & $55.5 d$ & $4.99(1 \mathrm{H}, \mathrm{m})$ & & & $45.1 \mathrm{t}$ & $4.38(2 \mathrm{H}, \mathrm{s})$ \\
\hline $2^{\prime \prime \prime}$ & $61.3 t$ & $3.83(2 \mathrm{H}$, br. $t, 5.1)$ & & $26.3 t$ & $2.25(1 \mathrm{H}, \mathrm{m})$ & & & $172.8 \mathrm{~s}$ & \\
\hline & & & & & $2.49(1 \mathrm{H}, \mathrm{m})$ & & & & \\
\hline $3^{\prime \prime \prime}$ & & & & $31.9 t$ & $2.40(2 \mathrm{H}, \mathrm{m})$ & & & & \\
\hline $4^{\prime \prime \prime}$ & & & & $176.3 \mathrm{~s}$ & & & & & \\
\hline $5^{\prime \prime \prime}$ & & & & $173.9 \mathrm{~s}$ & & & & & \\
\hline
\end{tabular}

$\mathrm{CD}_{3} \mathrm{OD}$ was used for an internal standard as $\delta_{\mathrm{H}} 3.31$ and $\delta_{\mathrm{C}} 49.15$. Urea was used for an external standard as $\delta_{\mathrm{N}} 75$. a: Multiplicity by DEPT experiment. ${ }^{\text {b: }}$ Assignments are interchangeable.

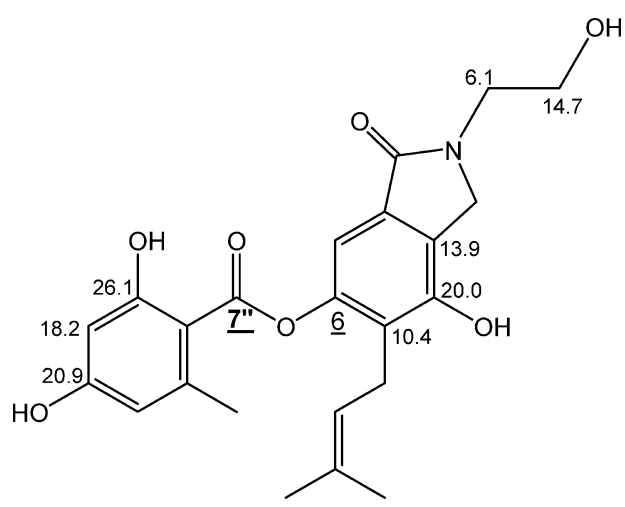

Fig. 4 Deuterium shift $\left(\Delta \delta_{\mathrm{CH}_{3} \mathrm{OH}-\mathrm{CD}_{3} \mathrm{OD}}\right.$ in $\left.\mathrm{Hz}\right)$ of sterenin $\mathrm{A}$. desalted by extraction with EtOAc $(700 \mathrm{ml})$. The solvent layer was washed with saturated brine $(600 \mathrm{ml})$ and dried over anhydrous $\mathrm{Na}_{2} \mathrm{SO}_{4}$ for 1 hour. Filtered extract was concentrated in vacuo to dryness to yield crude material $(335 \mathrm{mg})$. Part of it $(130 \mathrm{mg})$ was dissolved into $\mathrm{MeOH}$ $(2.0 \mathrm{ml})$ and a $200 \mu \mathrm{l}$ portion was applied to a preparative HPLC (column; Capcell Pak C18 UG120, 20×250 mm, mobile phase; $\mathrm{CH}_{3} \mathrm{CN}-\mathrm{H}_{2} \mathrm{O}(37: 63)$ containing $0.05 \%$ $\mathrm{HCOOH}$, flow rate; $10 \mathrm{ml} /$ minute, detection; $\mathrm{UV}$ at $210 \mathrm{~nm}$ ). Preparations performed ten times obtained four isolated fractions which contained active compounds. Each fraction was concentrated in vacuo to remove the $\mathrm{CH}_{3} \mathrm{CN}$ and, after freeze drying, they yielded pure sterenin A (24 mg), B (25 mg), C (11 mg) and D (10 mg) as white 
powders.

\section{Physico-chemical Properties}

The physico-chemical properties of sterenin A, B, C and D are summarized in Table 1. The molecular formulae of these compounds were determined mainly by highresolution FAB-MS. Sterenin A, B, C and D possess the molecular formulae of $\mathrm{C}_{23} \mathrm{H}_{25} \mathrm{NO}_{7}, \mathrm{C}_{26} \mathrm{H}_{27} \mathrm{NO}_{10}, \mathrm{C}_{21} \mathrm{H}_{21} \mathrm{NO}_{6}$ and $\mathrm{C}_{23} \mathrm{H}_{23} \mathrm{NO}_{8}$ based on their ions of $[\mathrm{M}+\mathrm{Na}]^{+},[\mathrm{M}+\mathrm{H}]^{+}$, $[\mathrm{M}+\mathrm{Na}]^{+}$and $[\mathrm{M}+\mathrm{H}]^{+}$, respectively. The ${ }^{13} \mathrm{C}$ - and ${ }^{1} \mathrm{H}-$ NMR spectral data of sterenin A, B, C and D observed in
$\mathrm{CD}_{3} \mathrm{OD}$ are shown in Table 2. These NMR spectral data suggest that their structures are closely related to each other.

\section{Structure Elucidations}

\section{Sterenin A}

The structure elucidation of sterenin A was carried out mainly by NMR spectral analysis. DEPT experiments revealed the presence of 3 methyl carbons, 4 methylene carbons, 4 methine carbons and 12 quaternary carbons. Assignments of the ${ }^{1} \mathrm{H}$ and ${ }^{13} \mathrm{C}$ signals were performed by

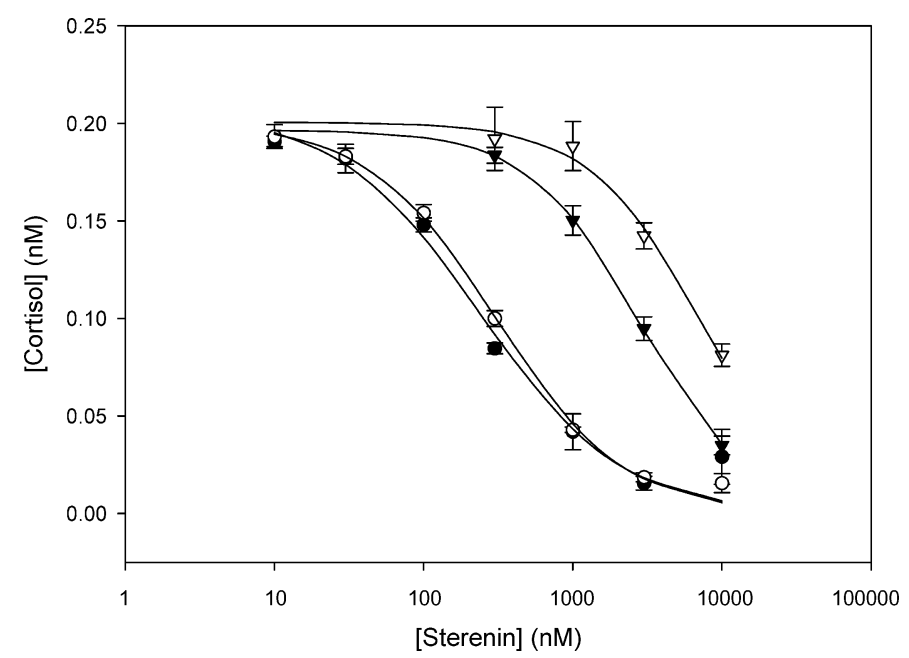

Fig. 5 Effects of sterenin derivatives on human $11 \beta$-HSD1 activity.

๑: Sterenin A, $\nabla$ : sterenin B, O: sterenin C, $\mathbf{\nabla}$ : sterenin D.

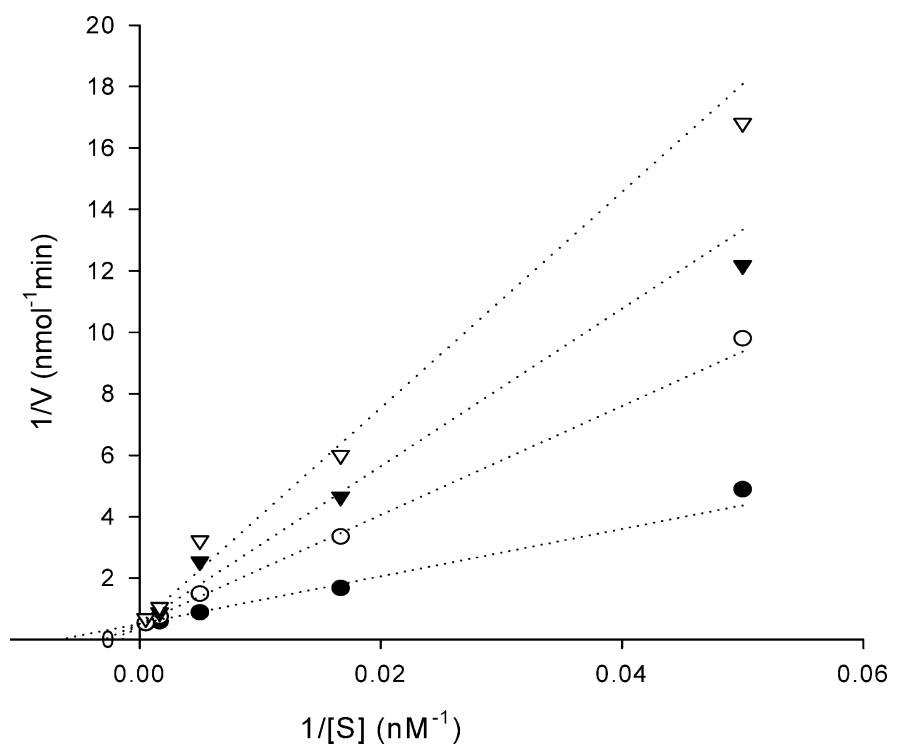

Fig. 6 Lineweaver-Burk plots for inhibition of human $11 \beta$-HSD1 by sterenin A.

- None, $\bigcirc 100 \mathrm{nM}, \boldsymbol{\nabla} 150 \mathrm{nM}, \nabla 225 \mathrm{nM}$. 
Table 3 Inhibitory activities of sterenin derivatives to human $11 \beta$-HSD isoforms

\begin{tabular}{crc}
\hline & \multicolumn{2}{c}{$\mathrm{IC}_{50}(\mathrm{nM})$} \\
\cline { 2 - 3 } Sterenin & $11 \beta$-HSD1 & $11 \beta$-HSD2 \\
\cline { 2 - 3 } A & 240 & $>10000$ \\
B & 6600 & $>10000$ \\
C & 230 & $>10000$ \\
D & 2600 & $>10000$ \\
\hline
\end{tabular}

detailed analysis of the DQF-COSY, HSQC and HMBC data. The observed ${ }^{1} \mathrm{H}-{ }^{13} \mathrm{C}$ and ${ }^{1} \mathrm{H}-{ }^{15} \mathrm{~N}$ long-range couplings shown in Fig. 3 revealed isoprenylisoindolinone and $o$ orsellinic acid moieties.

The connectivity of these two partial structures was clarified by a deuterium shift experiment using samples in $\mathrm{CD}_{3} \mathrm{OD}$ and in $\mathrm{CD}_{3} \mathrm{OH}$ in a coaxial tube. The shift values in $\mathrm{Hz}\left(\Delta \delta_{\mathrm{CH}_{3} \mathrm{OH}-\mathrm{CD}_{3} \mathrm{OD}}\right)$ are shown in Fig. 4 . All the carbon signals within the two-bond distance from the applicable oxygen atoms except for those around positions 6 and 7 " exhibited deuterium shifts and the isoprenylisoindolinone and $o$-orsellinic acid were thereby linked via an ester bond at C-6 and C-7". Thus, the structure of sterenin A was elucidated as shown in Fig. 1.

\section{Sterenin B, C and D}

According to the NMR analysis of sterenin B, C and D shown in Fig. 3, it was concluded that they were different analogues based on variations of the $N$-linked side chain in sterenin A (Fig. 1).

\section{Biological Activities}

Sterenin homologues inhibited human $11 \beta$-HSD1 activity in a dose-dependent manner (Fig. 5). To analyse the $11 \beta$ HSD1 inhibition mechanism of sterenin A, we performed a kinetic analysis. The Lineweaver-Burk plots revealed that sterenin A behaved as a competitive inhibitor (Fig. 6). The $K i$ value of sterenin A was calculated to be $68 \mathrm{nM}$. The inhibitory effects of all the homologues were isoform specific, as they did not inhibit human $11 \beta$-HSD2 (Table $3)$.

\section{Discussion}

In the present study, we report the discovery of novel $11 \beta$-HSD1 inhibitors named sterenin A, B, C and D from a solid-state culture of producing basidiomycetes identified as Stereum sp. SANK 21205. Among various kinds of reported isoindolinone type alkaloids, 2,5-dimethyl-6methoxy-4,7-dihydroisoindole-4,7-dione [9], described as the first naturally-occurring isoindole with antibacterial activity from sponge, stachybotrins [10] with antibacterial and fungicidal activities, staplabin [11] and a series of compounds named SMTPs [12 16] as tissue plasminogen modulators, are listed as related compounds. During the screening process, we isolated stachybotrin homologues, but their inhibitory activities against human $11 \beta$-HSD1 were approximately ten times weaker than those of sterenin $\mathrm{A}$ and $\mathrm{C}$ (data not shown). To the best of our knowledge, this is the first report of natural products which possess potent $11 \beta$-HSD1 inhibitory activities.

From the standpoint of the producing organism, there is literature that comments on Stereum hirsutum, which belongs to the same genus as the strain SANK 21205, and which produces a related compound named MS-3 [17 19]. Although this compound was reported to be a glyoxalase I inhibitor and a growth inhibitor of sarcoma cells in vitro, MS-3 would be one of the precursors of sterenin homologues in terms of biosynthesis.

As described above, sterenin derivatives are potent competitive inhibitors with strict selectivity against $11 \beta$ HSD1 versus $11 \beta$-HSD2. It is intriguing to note that sterenin $\mathrm{A}$ and $\mathrm{C}$ possess ten to thirty times stronger activities than those of sterenin B and D. Among these homologues, sterenin B exhibited the weakest inhibitory activity. In view of the contribution of its stereochemistry to the activity, we did not determine the configuration of sterenin B. It is possible to say that the size and/or charge of the $N$-linked side chain on the isoindolinone skeleton play a critical role in the inhibitory activity. Further structure-activity relationship (SAR) studies will be needed to determine the usefulness of sterenins against Type 2 diabetes and metabolic syndrome. The total synthesis of sterenins and the X-ray crystallographic analysis of their enzyme complexes will be separately reported elsewhere.

\section{References}

1. Seckl JR, Walker BR. 11 $\beta$-Hydroxysteroid dehydrogenase type 1 -A tissue-specific amplifier of glucocorticoid action. Endocrinology 142: 1371-1376 (2001)

2. Montague CT, O'Rahilly S. The perils of portliness: causes and consequences of visceral adiposity. Diabetes 49: 883-888 (2000)

3. Livingstone DEW, Kenyon CJ, Walker BR. Mechanisms of 
dysregulation of 11 $\beta$-hydroxysteroid dehydrogenase type 1 in obese Zucker rats. J Endocrinol 167: 533-539 (2000)

4. Rask E, Olsson T, Soderberg S, Andrew R, Livingstone DEW, Johnson O, Walker BR. Tissue-specific dysregulation of cortisol metabolism in human obesity. J Clin Endocrinol Metab 86: 1418-1421 (2001)

5. Paulmyer-Lacroix O, Boullu S, Oliver C, Marie-Christine Alessi MC, Grino M. Expression of the mRNA coding for $11 \beta$-hydroxysteroid dehydrogenase type 1 in adipose tissue from obese patients: An in situ hybridization study. J Clin Endocrinol Metab 87: 2701-2705 (2002)

6. Kotelevtsev Y, Holmes MC, Burchell A, Houston PM, Schmoll D, Jamieson P, Best R, Brown R, Edwards CRW, Seckl JR, Mullins JJ. 11 $\beta$-Hydroxysteroid dehydrogenase type 1 knockout mice show attenuated glucocorticoidinducible responses and resist hyperglycemia on obesity or stress. Proc Natl Acad Sci USA 94: 14924-14929 (1997)

7. Masuzaki H, Paterson J, Shinyama H, Morton NM, Mullins JJ, Seckl JR, Flier JS. A transgenic model of visceral obesity and the metabolic syndrome. Science 294: 2166-2170 (2001)

8. Chamuris GP. The non-stipitate stereoid fungi in the northeastern United States and adjacent Canada. Mycological Memoir 14: 93-98 (1988)

9. Frincke JM, Faulkner DJ. Antimicrobial metabolites of the sponge Reniera sp. J Am Chem Soc 104: 265-269 (1982)

10. Xu X, de Guzman FS, Gloer JB, Shearer CA. Stachybotrins $\mathrm{A}$ and B: Novel bioactive metabolites from a brackish water isolate of the fungus Stachybotrys sp. J Org Chem 57: 6700-6703 (1992)

11. Shinobara C, Hasumi K, Hasumi W, Endo A. Staplabin, a novel triprenyl phenol which stimulates the binding of plasminogen to fibrin and U937 cells. J Antibiot 49: 961-966 (1996)

12. Kohyama T, Hasumi K, Hamanaka A, Endo A. SMTP-1 and -2, novel analogs of staplabin produced by Stachybotrys microspora IFO30018. J Antibiot 50: 172-174 (1997)

13. Hasumi K, Ohyama S, Kohyama T, Ohsaki Y, Takayasu R, Endo A. Isolation of SMTP-3, -4, -5 and -6, novel analogs of staplabin, and their effects on plasminogen activation and fibrinolysis. J Antibiot 51: 1059-1068 (1998)

14. Hu W, Ohyama S, Hasumi K. Activation of fibrinolysis by SMTP-7 and -8, novel staplabin analogs with a pseudosymmetric structure. J Antibiot 53: 241-247 (2000)

15. Hu W, Kitano Y, Hasumi K. SMTP-4D -5D, -6D -7D and $-8 \mathrm{D}$, a new series of the non-lysine-analog plasminogen modulators with a D amino acid moiety. J Antibiot 56: 832-837 (2003)

16. Hasumi K, Hasegawa K, Kitano Y. Isolation and absolute configuration of SMTP-0, a simplest congener of the SMTP family nonlysine-analog plasminogen modulators. J Antibiot 60: 463-468 (2007)

17. Kurasawa S, Takeuchi T, Umezawa H. Studies on glyoxalase inhibitor: Isolation of a new active agent, MS-3, from a mushroom. Agric Biol Chem 39: 2003-2008 (1975)

18. Kurasawa S, Naganawa H, Takeuchi T, Umezawa H. The structure of MS-3: A glyoxalase I inhibitor produced by a mushroom. Agric Biol Chem 39: 2009-2014 (1975)

19. Nakamura H, Iitaka Y, Kurasawa S, Takeuchi T, Umezawa H. The crystal structure of a dibromo-derivative of MS-3: A glyoxalase I inhibitor produced by a mushroom, Stereum hirsutum. Agric Biol Chem 40: 1781-1784 (1976) 